\title{
TYPES OF TEACHER TALK TO SUPPORT STUDENTS' ACTIVENESS IN ONLINE CLASSROOM
}

\author{
Rina Yuliana ${ }^{1}$, Ratna Dewi ${ }^{2}$, Bahrun Amin ${ }^{3}$ \\ Jln. Sultan Alauddin No.259, Makassar, Universitas Muhammadiyah Makassar, Indonesia \\ rinayuliana962@gmail.com, ${ }^{2}$ ratnadewi@unismuh.ac.id, ${ }^{3}$ bahrunatawa@gamil.com
}

\begin{abstract}
This study concerned with teacher talk in online classroom. The interaction between teacher and students are analyzed into types of teacher talk. The aim of this study is to find it types of teacher talk to support students' activeness in online classroom. Descriptive qualitative design was used as research methodology. The researcher was a non-participating observer in online class. There were two teachers involved as research participants. The participants conducted online class by using Zoom Application. Video recording from Zoom was analyzed by applying three steps, which consisted of reading or memoing data, describing data, and classifying data. In analyzing the data, the researcher referred to types of teacher talk by Brown who classified teacher talk into seven types. The research findings found there were five types of teacher talk in online classroom. Those are praising and encouraging, accepting ideas of students, asking questions, lecturing, and giving direction. These types found are used to support the students' activeness in online classroom. Therefore, active and passive students are related to teacher talk. This study is implied to be used as reference to be applied by the teachers to keep the students active in online classroom.
\end{abstract}

Keywords: Activeness; Online Classroom; Teacher Talk; Types

\begin{abstract}
ABSTRAK
Penelitian ini berkaitan dengan percakapan guru di dalam kelas online. Interaksi antara guru dan peserta didik dianalisis ke dalam bentuk percakapan guru. Tujuan penelitian ini adalah untuk menemukan bentuk percakapan guru yang dapat mendukung keaktifan peserta didik dalam pembelajaran online. Penelitian ini menggunakan kualitatif deskripsi sebagai metode penelitian. Peneliti bertindak sebagai pengamat non participant dalam pembelajaran online. Terdapat dua guru terlibat sebagai peserta penelitian. Peserta penelitian menggunakan aplikasi zoom. Rekaman dari zoom dianalisis dengan mengaplikasikan tiga langkah yaitu membaca data, mendeskripsikan data, dana mengklasifikasikan data. Dalam menganalisis data, peneliti merujuk pada bentuk percakapan guru oleh Brown (2007) yang mengklasifikasikan percakapan gurun ke dalam tujuh bentuk. Hasil penelitian menemukan lima bentuk percakapan guru di dalam kelas online yaitu memuji dan membesarkan hati, menerima ide peserta didik, memberikan pertanyaan, memberikan kuliah, dan memberikan arahan. Bentuk percakapan yang ditemukan ini digunakan untuk mendukung keaktifan peserta didik di dalam kelas online. Oleh karena itu, peserta didik aktif dan pasif berhubungan dengan percakapan guru.
\end{abstract}

Kata Kunci: Keaktifan; Kelas Online; Percakapan Guru; Bentuk 


\section{INTRODUCTION}

Nowadays, Covid-19 pandemic affects learning activities in the world. Almost all teachers conduct their teaching in an online classroom. Online classroom is the best alternative to teach the students in this situation. In English Foreign Language (EFL) online classrooms, the interaction of teacher and students, student with students are an important part in learning activities, even in offline class. The quality of the interaction between teacher and student supports the teaching learning process. It is supported by (Pujiasuti, 2013) who stated that the qualities and quantities of teacher talk have many values in learning activities. Similar to (Brown, 2019) who pointed out that the interaction was through collaborative exchange, ideas or feelings of teacher and students; and learners and learners and a learner to others learners.

Teacher talk is essential in the teaching and learning process. As (Nasir, 2018) supported that teacher talk plays an important role in classroom interaction because it could facilitate students to increase their comprehension level on the learning materials and it can enhance students in order to be active in learning activities. Moreover, teacher talk also supports students in practicing the language. This view is supported by (Tsui, 2001) who stated that teacher talk is a determiner of student's output due to some categories of teacher talk such as questioning strategies affects the tendency of learners strategies in producing language. Therefore, the teacher's job is how their talks can enforce a student's language production.

In addition, the crucial factors of learning activities are the interaction between teacher and students, particularly in classroom discussion and presentation. However, the lack of teacher-student interaction is an obstacle to the learning process. For instance, when there is no response from students to the teacher's instruction because the teacher talks most of the time, it indicates that interaction does not run well in the classroom. Dealing with this obstacle the teacher needs to behave in their role as a good communicator to promote the interaction in the classroom. In line with (Abdul, 2020) who concluded that the teacher is a communicator in the classroom to inform all instructional materials. Therefore, it is important to the teacher to be selective in choosing what they present to students. The materials should be meaningful to the students and presented communicatively.

Research studies around teachers in EFL classrooms have been done extensively. Several studies which have been done such as; (Arellano, 2018) found that the interactions in the lesson are dominated by the teacher and also the questions the teacher asked do not have real communication or higher order thinking. Similar to (Sofyan \& Mahmud, 2018) who use FLINT system to analyze teacher talk in learning activities, their study found teacher talk was made in discussion of group and pair to keep balance the effectiveness of students in the learning and interaction process. JaeHwang (2010) showed that teacher talk dominates most of the teaching and learning process in classroom interaction. 
In classroom interaction, a teacher has an important role to facilitate learning activities. The language used in talking about the materials should be clear to students, because language is a communication tool (Abdul 2020), therefore the teacher has to communicate teaching materials effectively. (Mulyati, 2013) stated that the teacher behaves as the most dominant interlocutor in speaking activity. Moreover, it found that the teacher has some roles during interaction; they are as director, manager, and facilitator. The research suggested the teacher should support students to have more opportunity to tell their ideas during the lesson.

Additionally, (Nasir, Yusuf \& Wardana, 2019) also found that one of the importances of teacher talk is it could help students to promote comprehension of students' level toward the instructional materials. Teacher talk encourages students to be active in the process of teaching and learning. The results also showed that the students are giving direction. Besides, giving direction which occurred in learning activities are regarded as the most implemented by the teachers. It is indicated that most of the teachers provided and managed their students by directing, commanding, or ordering in learning activities. It was found also that the students are less participation in expressing ideas and feeling in learning and interaction activities.

Furthermore, (Putri, 2015) denoted that the type of teacher talk in class interactions indicates indirect influence to show the students understanding of the topic taught which the analysis uses FLINT to classify teacher talk. The gathered data from the observation sheet and questionnaire indicates the teacher's talk influences students in learning activities. The questions are administered to students as a technique to find out students' ability in the lesson. Moreover, the teacher created some types of teacher talk, such as accepting students' ideas or feelings, praising or encouraging, and using students' ideas. Almost all students perceived that the teacher reflects indirect influences in learning activities.

Some researchers showed that classroom interaction of English subjects is still controlled by the teacher in the class. It is the most common in the middle of the teaching and learning process. So teacher talk time can decrease opportunities for students talking time. Some other researchers found that teacher talk has an important role in students' learning because it could facilitate them to develop their skill. In this case, the inputs of teacher talk will have positive or negative effects on students' skill output in language learning. Therefore, the key factor for foreign language acquisition is comprehensible input. In foreign language classroom teaching process, teacher talk (TT) is the input and it is the most reliable source of students' "input" (Wang 2014). Therefore, teacher talk is important to students' comprehension of acquiring language.

Based on the previous related studies, it could be stated that there are similarities and differences with this research. The previous researchers focus on the research on amount of teacher talk (Ahmad, Syakir, \& Arshad, 2020), analyzing speech act in the classroom (Basra and Tohiyyibah, 2017), function of teacher talk (Jing and Jing, 2018), teacher talk about students' ability and achievement (Datnow, 
Choi, Park, \& John, 2018), while (Yanfen \& Yuqin, 2010) examine the interaction of teacher and students. Those researches focus on teacher talk in the classroom. Similar to this study that investigates teacher talk, but it focused on types of teacher talk to promote students' activeness in online classrooms.

This study was conducted in SMPN 1 Parangloe, Gowa Regency, where all teachers use online classrooms for conducting teaching and learning processes. Online classroom is chosen because Gowa regency itself is one of the red zones, where the number of patients of Covid-19 increased and this school has to close temporarily. It can be stated that using online teaching is the best way to keep the student learning. The teachers use some learning platforms in online classrooms such as google classroom, google meet, zoom, email, and WhatsApp group to explain the materials. In an online classroom, the teacher and student can still communicate and interact about the lesson. Therefore, this leads the researcher to investigate teacher talk in classroom interaction.

\section{LITERATURE REVIEW}

\section{Definition of Teacher Talk}

Talk in the classroom refers to teacher and students talking and interacting to each other. Talks are teachers' ways in delivering information in this case instructional materials and their talks are used to control students' attitude (Allwright and Bailey, 1991:139).

Additionally, teacher talk also plays an essential role in learning activities. Teacher talk gave an impact toward students' interaction in learning activities.. According to (Yanfen \& Yuqin, 2010:77), they found that the appropriate teacher talk could create a positive environment in the class and it can facilitate friendly communication between teacher and students. Teacher talks are also regarded to be able to give more opportunities for them to interact with each other. There are many interactive strategies that were found to make students more interactive in learning activities. It consists of repetition, prompting, prodding, and expanding.

Allwright and Bailey in (Pangesti, 2016) claimed that talk is one of the major ways to deliver information. The teachers use talk to convey the instructional materials to students. Besides, the talks are used to control students' behavior in learning activities in the class. This case indicates that the teacher talk has an essential function of language teaching in English foreign language teaching, where it is used to convey meaning of instructional materials.

Furthermore, (Yanfen \& Yuqin, 2010) stated that teacher talk is an indispensable part of foreign language teaching in organizing learning activities in the classroom. The way teachers talk not only determines how well they make their lectures, but also guarantees how well students learn. So teacher talk or the language used by the teacher has an important role that influences the success of English 
teaching learning process. Teacher talk also is used to guide the learning a joint and share the educational knowledge with the students. In addition, teacher talk can offer useful and applicable language practice which gives benefits to the students. Both teacher and students used talk to interact with one another.

(Nunan, 1991) points out: "Teacher talk is of crucial importance, not only for the organization of the classroom but also for the processes of acquisition. It is important for the organization and management of the classroom because it is through language that teachers either succeed or fail in implementing their teaching plans. In terms of acquisition, teacher talk is important because it is probably the major source of comprehensible target language input the learner is likely to receive." It can be stated that the amount and type of teacher talk is even regarded as a decisive factor of success or failure in classroom teaching.

Furthermore Ellis in (Xio-Yan, 2006) formulated about teacher talk that teacher talk is the special language that teachers use when addressing L2 learners in the classroom. There is systematic simplification of the formal properties of the teacher's language and teacher talk can be divided into those that teachers use in language classrooms and those that investigate the type of language they use in subject lessons.

Based on the definition above, it can be concluded that teacher talk in English as a foreign language classroom is regarded as one special variety of the English language. It has its own specific features which other varieties do not share. Because of the restriction of the physical setting, special participants as well as the goal of teaching, teacher talk has its own style. Moreover, it can be said that teacher talk is a special communicative activity which has meaning to the students. Its goal is to communicate with students and develop students' foreign language proficiency.

\section{Categories of Teacher Talk}

talk:

According to (Brown, 2007) describes the following categories of teacher

a. Deal with Feelings

Dealing with feelings, it refers to students' feelings in communication. It is important to show feelings in classroom activities. Student's experiences could shape their minds, the reason behind their feelings in the present time, and it can help them to avoid the trauma of students. The teacher's understanding in applying the right way could handle students' feelings. It also will comfort the interaction of teacher and students interaction in the classroom.

b. Praises and Encourages

Teacher activities in teaching are not only focused on conducting lesson plans and developing teaching materials but also motivating students to raise their 
motivation in order to find and design students' language skills. Motivation should be done as well as, so the significance of the lesson can be achieved as mentioned in the lesson plan. In doing daily activities, teachers could support students by giving praise, compliment, and tell them that their ideas and works are valuable and meaningful. Sometimes, it is found that some students may feel stuck and blank in the middle of their speaking performance.

c. Using Students' Ideas

Teacher's attention to students' contribution is a great appreciation for students' works. Some ways in expressing the appreciation, such as clarifying, using, interpreting or summarizing the ideas of students. Teachers can start a discussion based on students' ideas by rephrasing them but still recognized as students' contribution.

d. Asking Questions

As it brought before in previous pages, questioning in the intersection is a way to motivate students speaking up their thoughts or ideas. There are many ways to classify kinds of questions for classroom effectiveness. The questions can be classified by the level of the students. Usually, the teacher begins with displaying questions which the answers are common knowledge. The display questions can be used to provoke the students' ideas and their language form.

e. Giving information

Giving information refers to a classic teaching method where the teacher gives information, facts, personal opinion, or ideas about a topic. It simply gives students the lecture or asks rhetorical questions. Nowadays, this method is considered an out-of-date method for teaching and learning because students should be active in the classroom. To avoid this kind of method, it does not mean that the teacher leaves the whole classroom activities to the students. Teacher has to conduct lesson plans and develop material so he/she can stimulate students' behavior.

f. Giving Directions.

There are many learning activities that can be implemented in speaking class for classroom interaction. Students have good opportunities to explore their ideas and feelings. However, they need some directions and facilitations of information on how they should demonstrate their own ideas systematically. They expect clear directions or commands from their teacher. So the teacher should direct them to do various exercises and facilitate them by working in groups.

g. Criticizing Student Behavior

This type refers to students who are difficult to handle in learning activities. From students' age, there are many internal problems found such as puberty 
and unstable emotion. When this situation occurs, the teacher should communicate anger and annoyance with students.

\section{RESEARCH METHOD}

The research used a descriptive qualitative method in order to describe the types of talks used by the teachers and students and explore the real situation that happens in online classrooms, especially in the class where the teaching and learning process is conducted.

The research was conducted in an English Foreign Language classroom at SMP 1 Bontonompo Gowa Regency. The participants of this research were the English teacher and the students of grade seven in academic 2020/2021. The number of students was 35 students and two teachers.

To collect data, the researcher used two kinds of instruments, namely observation notes/sheets and interview protocol;. The observation notes/sheets are used to write all expressions of talks produced by the teachers and the students in the interaction during the teaching and learning process. Since it will be quite hard to cover all expressions during the interaction, the recording will also be provided in order to cover all the talks produced. So, both observation sheets and recordings have the same purpose. The interview instrument was used to collect data related to types of teacher talk in online classrooms. In this research, there were two kinds of interviews used, namely personal interview and focus group interview. Type of the interview was a semi-structured interview in which protocol questions are prepared before interviewing and some possible questions are asked on the spot. It contains the outline of the interview topics that may be necessary to be asked to the participant. In spite of this interview, the researcher developed new questions if necessary.

Data Analysis, the researcher analyzed the data from observation and interview collected. The data were analyzed based on Gay et al. (2006), there are three steps in analysis data:

1. Reading/Memoing Data. The first is reading or memoing, where the researcher reads data that has been collected from the start starting from observation to data from interviews.

2. Describing Data. After gathering the data from observation and interview, the second was describing data. In this case, the researcher overviewed the data generated in general that can be obtained from reading and scraping data. In this step, the first question was answered from the research question about teacher talk and students talk in online classrooms. After that the data was classified into teacher talk which covered talk to influencing students' activeness and persuading students' communication in English; and students talk to express their participation and interest in online classroom.

3. Classifying Data. The final stage in the analysis of qualitative data is classifying. The researcher classified teacher talk which covered talk to influence students' 
activeness and persuade students to communicate in English; and students talk covers and students talk to express their participation and interest in online classroom. The researcher transcribed the results, summarized the findings, and drew some conclusions from such findings. In this step, the researcher broke down through the process of classifying or coding and categorizing pieces of data and grouping them into themes.

\section{FINDING AND CONCLUSION}

\section{Findings}

There four findings presented based on research objectives, the data were taken from zoom video in an online classroom. The results of this study are shown in the following part. Based on the data collected, types of teacher talk used by the teacher to support the activeness of students talk in online classroom are as follows:

a. Praises and Encourages

The teacher gives praise or encouragement to support the students to be active in the online classroom. The teacher talk is as follows:

Teacher: okay bagus, who others can give example ada lagi yang bisa memberikan contoh selain yang disebutkan Sisi Wahyuni? Extract 01

Teacher : good, itu salah satu contohnya yah...joni does not speak in English. Kalo Wahyu bisa membuat kalimat?can you make sentence yang menyatakan tidak misalnya saya tidak makan kue atau apa yang sudah ditulis Extract 02

Extract 01 and extract 02 indicate that the teacher gives praise or encouragement on students' response. The teacher says good to the student who answers the question given. The teacher also encourages the other students to make sentences about present tense. In order to make sure the students understand the instruction, the teacher switches the language into Bahasa Indonesia.

Teacher : perhatikan layar kalian, siapa yang bisa baca yang dilayar?

Students : we will learn to ask for and give information related to actions/functions of people, animals and things in order to identify, to criticize or to praise them.

Teacher : we will learn to ask for and give information related to actions/functions of people, animals and things in order to identify, to criticize or to praise them. Anyone of you understand the meaning? Ada yang tau apa artinya?

Students : :kita akan mempelajari ...

Teacher : mention your name? sebutkan namanya dan jawab I will give you star, saya mau kasi kamu bintang yang menjawab dengan benar. Siapa 
yang bisa menjawab? Extract 03

Extract 03 indicates teacher talk that encourages students to respond to the questions. The teacher repeats several times to call the students to answer the question. Repeating is used to make sure the question given is clear to the students. Moreover, when no one of the students wants to try to answer the question, the teacher encourages them by promising that the students who can answer the question correctly will get a star. The teacher also mixes and switches the language, it is because to ensure the talk is meaningful to the students.

b. Accepting or Using Ideas of Students

Student : saya bu, saya tidak mempunyai pulpen I don't have pen

Teacher: Sisi Wahyuni memberikan contoh tadi itu I do not have pen saya tidak mempunyai puplen adalah bentuk kalimat negative dalam simpe present tense. Okay siapa lagi yang bisa memberikan contoh...bisa memberikan contoh bagaimana membuat kalimat simple present tense bisa pake kalimat postivie, bisa pake kalimat negative, bisa pake kalimat tanya. Wahyu please, atau yang lain siapa namanya nak? Extract 04:

Extract 04 shows the teacher asking the students to give examples of simple present tense, and one of the students tries to answer. In this case, the teacher did not determine the pattern of the sentence, but students are free to construct their own sentence. For this situation, teacher talk describes accepting students' ideas. The example given by the student is accepted and the teacher gives an explanation related to the example.

c. Asking Questions

Teacher: Masih ingat..in English e...give example what is er..sentence in simple present tense?...now one of you give example. Siapa yang bisa memberikan contoh? Sisi Wahyuni can you give example sentence in simple present tense?

Student 1: Do you speak in English?

Teacher: okay bagus, who others can give example ada lagi yang bisa memberikan contoh selain yang disebutkan Sisi Wahyuni?

Student 2: The dogs barks....

Teacher: Okay Arjun nda kedengaran suaranya ... Okay Sisi boleh angkat tangan. Extract 05

Extract 05 indicates the interaction between teacher and students at the beginning of the class. The teacher reminds the students about the previous lesson. To review the last lesson, the teacher asks the question. The teacher also points to other students to answer the question. This type of teacher talk shows that giving questions could make the students active in the class. 
Teacher : apa itu old?ada yg tau age itu apa?klo kakek2 usianya itu apa?

Students : tua

Teacher : ya betul, kalo kakek2 itu tua umurnya. Ada juga itu middle age, umurnya Sedang atau paruh baya ada juga young .kalo anak kecil usianya apa?

Student : muda

Teacher : betul usianya muda. How is Najab like? Jadi bisa dia itu young,tall, dll. Kalo hansome apa? Extract 06

Extract 06 shows the teacher asking the students about the vocabulary. Students were asked to say the English word to Indonesian. The students can answer the questions correctly. Then, the teacher gave more questions to be translated. From the question and answer session, the students can participate actively.

Based on teacher talk on two extracts above, giving questions is one way to support the students' activeness in the classroom. The teachers stimulate students' skill by inviting them to respond to the question.

d. Lecture

Teacher : Jadi simple present tense itu nak yang menyatakan kejadian yang terus menerus terjadi atau yang berulang-ulang terjadi atau yang menceritakan tentant daily routine kebiasaan atau rutinitisa sehari-hari atau tentang kejadian yang biasa terjadi missal the sun shines every morning matahari bersinar setiap pagi seperti itu, tapi kalo kejadian yang seperti semalam atau kemarin malam yang seperti dicontohkan itu tidak bisa dikategorikan sebagai simple present tense sehingga tidak bisa dijadikan sebagai contoh. Siapa lagi yang bisa kasi contoh lain? Any other sentence?

Students : saya bu...saya mom...saya (some students rise their hand. Extract 07

Extract 07 shows the type of teacher talk in lecturing. The teacher gives a detailed explanation of the lesson and also provides examples. By lecturing, the students can recognize the materials and it helps them to be active to respond to the instruction given by the teacher. From the students' response above it means that after understanding the materials, they are active to answer the questions.

e. Giving Direction

Teacher : Very good Zulkarnain. Okay sekarang saya buat kalimat titik titik mam eat meatball? Titik titik ini diisi apa? Kalo saya bertanya apakah mam muji makan bakso?

Students : do...do..do..what

Teacher : okay bagug siapa itu menjawba?

Students : Pratama, Sisi Wahyuni Syam

Teacher : good, okay sekarang dengarkan dulu penjelasannya. Sudah 
bagus tapi ada sedikit kesalahan, do itu digunakan untuk subyek yg jamak, artinya lebih dari satu mam muji brp org?yah betul does, jadi does mam muji eat meat ball? Siapa itu tadi menjawab?mam muji cuma sendiri yah. Okay sekarang coba ini titik titik mam muji and sisi meatball?disini di titik titik apa? Berapa orang?

Students : dua orang

Teacher : yah dua orang mam muji dan sisi. Jadi two people yah. Titik titik diisi apa disini?

Students : do....do...do... Extract 08

Extract 08 indicates the teacher talks in giving direction. From the interaction, the teacher gives questions to students, but the students still look confused, so the teacher gives explanations. After that, the teacher gives another example but the teacher directs the students to find the correct answer. By directing the student, most of the students are active to answer the question.

f. criticize students behavior

Teacher : betul, itu namanya general appearance.selain itu kita juga bisa menanyakan sifatnya.

Students : saya keluar masuk zoom ku, saya juga mam...tit..tit [noisy]

Teacher : kasi off saja kameranya nak, atau cari tempat yang bagus. Yang lain matikan saja suarnya, bair tidak rebut. Oke perhatikan kembali. Ini adalah kata sifat seseorang. Seperti happy, inttleigent, diligent, hardworking. Apa itu hardworking itu apa?

Students :cerdas

Teacher : no, liat gamabrnaya, pekerja keras. Apa itu nervous?nerves itu gugup, cemas. Apa itu friendly Extract 9

Extract 9 shows talk used by the teacher to control students' noise in online class. The trouble signal makes it difficult for some students to hear the materials. When they try to respond, overlapping occurs because the students talk together at the same time and some of their talk is unclear. This situation leads the teacher to criticize students' behavior by telling them to turn the camera and microphone off.

\section{Discussion}

Teacher talk is very important in the classroom, because talk has meaning to the students. After conducting this study, the researcher found five types of teacher talk in the classroom. They praise or encourage; accepting or using ideas of students, asking questions, lecture, and giving direction. These types of teacher talk are used to support students' activeness in the classroom. Students' activeness depends on the teacher, it means how the teaching materials or learning activities to students (Abdul. 2020). The activeness of students in the classroom is also influenced by the teaching method and strategies by the teacher. As (Endhati \& Widagsa, 2018) who applied 
social media as a strategy to improve students participation and motivation in English subjects.

The first type of teacher talk used by the teacher in this study was praise and encouragement. The teacher gave praise to the students by saying good, very good, and good job. Similar to Crespo (2002) gives praise to students who give correct answers. This kind of talk is used to promote students' communication and discussion in the classroom. From the data, the teacher explained the materials and all learning activities via zoom. It is one of online platform learning tools in covid-19 pandemic. The teacher began the class by reviewing the previous materials, and encouraged the students to remember their lesson. During the activities, the teacher gave praise to appreciate their effort.

The second type of teacher talk was accepting or using ideas of students. The teachers asked for the students to state their ideas on the topic given. In this case the teachers accept all the students' opinions. When the teacher found there were passive students during the discussion, the teacher encouraged them by calling the name and told them to try stating their opinion. In line with Sert (2012) who implies that suggestions are needed to be talked about in the classroom to encourage student teachers to become more autonomous.

The third teacher talk type found in this study was asking questions. Both of the teachers as subjects of the research applied interactive learning. The teachers always gave questions to the students relating to the materials. The students were active to answer the question, even some of them gave the wrong answers. All of the students got praise from the teachers. Asking questions is effective talk to support students' activeness in the classroom. Aisyah (2016) found the teacher talk which most occurred in the classroom was asking questions. It indicates many teachers have the same ways to support the students' activeness. Similar to Qashoa (2013) stated that questioning is the most common and prominent classroom activity. The teachers' questions and students' answers are regarded as a powerful teaching approach.

The fourth type was lecturing. After reviewing the previous materials, the next lecture is lecturing the new topic. From the data, it is found that the teacher used the phone to write the materials and gave examples of sentences, and then the students focused on it. The teacher talks a lot about difficult materials to students. When the students looked confused the teacher repeated the explanation. Another teacher provided the materials in powerpoint. Lecturing is one way to improve students' cognitive skills. It is related to Morell (2007) who stated that the teacher needs to help the students, by giving lectures it helps them in understanding the content of the lesson and in appropriate the language.

The last type was giving direction. In conducting learning activities, the teacher has to direct the student in order they can follow all the instructions correctly. For instance, when the students gave the wrong answer, the teacher did not show the 
right wants directly but the teacher gave clues to direct them. It seems, this kind of teacher talk could help the students find the right answer.

\section{CONCLUSION}

Teacher talk is essential in the teaching and learning process. It will be meaningful to students. The teacher needs to keep attention on the quality of the talk. It is because the students can understand the material and follow all the instructions given when the teacher talks clearly to them. From the data in online classrooms, the teachers applied five types of teacher talk, namely praising and encouraging, accepting ideas of students, giving questions, lecturing, and giving direction. It can be stated that those types of teacher talk can be used in the classroom to support students' activeness.

\section{REFERENCES}

Abdul, N. B., Mahmud, M., Wello, B., \& Dollah, S. Instructional Communication: Form and Factors Affecting Students Participation at Higher Education Class.

Abdul, N. B. (2016). Psychological Barriers in Receptive Skills Acquisition. English and Literature Journal, 3(1), 42-51. Google Scholar

Ahmad, M., Shakir, A., \& Arshad, A. (2020).A conversation analysis of teacher talk and learners' involvement in a Pakistani ESL classroom. Pakistan Journal of Educational Research and Evaluation, 8(1), 20-42. Google Scholar

Aisyah N. (2016) an Analysis of Teachers' Talk in EFL Classroom, Department of English Education, Indonesia University of Education. Google Scholar

Allwright, D., \& Bailey, K. M. (1991). Focus on the language classrooms: An introduction to classroom research for language teachers. Cambridge University Press. Google Scholar

Basra, S., \&Thoyyibah, L. (2017). A speech act analysis of teacher talk in an EFL classroom. International Journal of Education, 10(1), 73-81. Google Scholar

Brown, D. (2007). Teaching by Principles.San Fransisco State University. United State of America: Pearson Longman

Crespo, S. (2002). Praising and correcting: Prospective teachers investigate their teacherly talk. Teaching and Teacher Education, 18(6), 739-758. Google Scholar

Datnow, A., Choi, B., Park, V., \& St John, E. (2018). Teacher Talk about Student Ability and Achievement in the Era of Data-Driven Decision Making. Teachers College Record, 120(4), n4.

Endahati, N., \&Widagsa, R. (2018). Social Media as Strategy to Improve Students' 
participation And Motivation In English Subject. English and Literature Journal, 5(2), 161-172. Google Scholar

Gay, L. R. (2006). Educational Research, Competencies for Analysis andApplication. Eight Edition. Columbus, Ohio: Merrill Prentice Hall, PearsonEducation Inc. Google Scholar

Hwang, J. S. (2012). A Study of the Cognition and the Requirement on the Key Competency of Dental Technology. The Journal of Korean Academy of Dental Technology, 34(4), 457-469. Google Scholar

Jing, N., \& Jing, J. (2018). Teacher talk in an EFL classroom: A pilot study. Theory and Practice in Language Studies, 8(3), 320-324. Google Scholar

Morell, T. (2007). What Enhances EFL Students' Participation In Lecture Discourse? Student, Lecturer And Discourse Perspectives. Journal Of English For Academic Purposes, 6(3), 222-237. Google Scholar

Mulyati A F. (2013). A Study of Teacher and Student Talk in Verbal Classroom Interaction to Develop Speaking Skill for Young Learners, English Education Program of Indonesia University of Education. Google Scholar

Nasir A, Yunisrina GY and Andri W. (2019).A Qualitative Study of Teacher Talk in an EFL Classroom Interaction in Aceh Tengah, Indonesia, University Syiah Kuala. Google Scholar

Nunan, David. 1991. Language Teaching Methodology: A Textbook for Teachers. Cambridge: Cambridge University Press. Google Scholar

Pangesti D. (2016). Teacher Talk in English Teaching and Learning Process at SMK Batik 1 Surakarta in 2015/2016 Academic Year, Muhammadiyah University Surakarta. Google Scholar

Pujiastuty RT. (2013). Classroom Interaction; an Analysis of Teacher Talk and Student Talk in English for Young Learners (EYL), English Education Study Program of Indonesia University of Education. Google Scholar

Putri AS. (2015). The Analysis of Teacher Talk and the Characteristics of Classroom Interaction in English as a Foreign Language Classroom, Dept. of English Education, Indonesia University of Education. Google Scholar

Qashoa, S. H. (2013). Effects of teacher question types and syntactic structures on EFL classroom interaction. The International Journal of Social Sciences, 7(1), 52-62 Google Scholar

Sert, N. (2006). EFL student teachers' learning autonomy. The Asian EFL Journal, 8(2), 180-201. Google Scholar

Sofyan RR anMurni M. (2018). Teacher Talk in Classroom Interaction: A Study an English Department in Indonesia, State University of Makassar, Indonesia. Google Scholar 
Tsui, A. B. (2001). Classroom interaction. The Cambridge guide to teaching English to speakers of other languages, 120-125.

Wang (2014) the Analysis of Teacher Talk in "Learner-centered" Teaching Model.International Journal of Education and Pedagogical Science

Xiao-yan M. (2006).Teacher Tal and EFL in University Classroom, Chongqing Normal University \& Yangtze Normal University, China. Google Scholar

Yanfen L and Yuqin.(2010). A Study of Teacher Talk in Interaction in English Classes, Harbin Institute of Technology. Google Scholar 